\title{
High performance ORR electrocatalysts prepared via one-step pyrolysis of riboflavin
}

\author{
Yuxiao Deng, Haixin Huangfu, Shuihua Tang *, Jie Li \\ State Key Laboratory of Oil and Gas Reservoir Geology \& Exploitation, School of Materials Science and Engineering, Southwest Petroleum University, \\ Chengdu 610500, Sichuan, China
}

\section{A R T I C L E I N F O}

\section{Article history:}

Received 4 May 2017

Accepted 3 July 2017

Published 5 October 2017

\section{Keywords:}

Riboflavin

Pyrolysis

Oxygen reduction reaction

$\mathrm{FeCl}_{3}$

Electrocatalyst

\begin{abstract}
A B S T R A C T
Efficient, cost-effective electrocatalysts for an oxygen reduction reaction (ORR) are currently required for fuel cells. In the present work, riboflavin was used as a cheap, nontoxic carbon and nitrogen precursor to prepare $\mathrm{Fe}-\mathrm{N}-\mathrm{C}$ catalysts via one-step pyrolysis in the presence of anhydrous iron chloride. Raman spectroscopy indicated that the catalyst containing nitrogen created a great quantity of defects in the carbon structures, while nitrogen adsorption-desorption isotherms showed that the catalyst was mesoporous. Transmission electron microscopy demonstrated that the $\mathrm{Fe}-\mathrm{N}-\mathrm{C}$ catalyst was composed of very thin, curved and porous graphene layers together with some $\mathrm{Fe}_{2} \mathrm{O}_{3}$ nanoparticles, and X-ray diffraction patterns confirmed that the carbon in the catalyst was highly graphitized. X-ray photoelectron spectroscopy indicated that the active sites for the ORR were primarily composed of graphitic nitrogen, although Fe sites also played an important role. The ORR activity of the Fe-N-C catalyst reached a maximum of $4.16 \mathrm{~mA} \mathrm{~cm}^{-2}$, and its chronoamperometric response was found to decrease by only 3\% after operating for $3 \mathrm{~h}$ at $0.66 \mathrm{~V}$ ( $v s \mathrm{RHE}$ ) in an $\mathrm{O}_{2}$-saturated $0.1 \mathrm{~mol} \mathrm{~L}-1 \mathrm{KOH}$ solution. In contrast, a commercial $40 \mathrm{wt} \% \mathrm{Pt} / \mathrm{C}$ catalyst with a loading of $0.2 \mathrm{mg}_{\mathrm{Pt}} \mathrm{cm}^{-2}$ exhibited an activity of $4.46 \mathrm{~mA} \mathrm{~cm}^{-2}$ and a $40 \%$ loss of response. The electrochemical performance of this new Fe-N-C catalyst was therefore comparable to that of the Pt/C catalyst while showing significantly better stability.
\end{abstract}

(C) 2017, Dalian Institute of Chemical Physics, Chinese Academy of Sciences. Published by Elsevier B.V. All rights reserved.

\section{Introduction}

The development of highly efficient, cost-effective electrocatalysts for the oxygen reduction reaction (ORR) has played an important role in the commercialization of proton exchange membrane fuel cells (PEMFCs) [1-4]. Currently, platinum-based catalysts are most commonly used as ORR electrocatalysts [5]. However, these materials are costly, which has restricted the implementation of PEMFCs [6]. Therefore, many attempts have been made to explore non-precious metal cata- lysts (NPMCs), including macrocycle-based catalysts [7-9], transition metal carbides [10-12], transition metal oxides [13], and $\mathrm{M}-\mathrm{N}-\mathrm{C}(\mathrm{M}=\mathrm{Fe}$ and/or $\mathrm{Co})$ catalysts [14-21]. Among these, the $\mathrm{M}-\mathrm{N}-\mathrm{C}$ materials are considered as one of the most promising candidates owing to their high activity and remarkable stability [22-25].

Dodelet et al. [26] used phenanthroline as a nitrogen source to synthesize an iron-based ORR electrocatalyst. This catalyst showed excellent performance, and the ORR volumetric activity and mass-transport of the material were found to be further

\footnotetext{
* Corresponding author. Tel/Fax: +86-28-83032879; E-mail: spraytang@hotmail.com

This work was supported by Open Project from State Key Laboratory of Catalysis (N-14-1), Scientific Research Foundation for Returned Scholars, Ministry of Education of China, and International Technology Collaboration of Chengdu Science and Technology Division.
}

DOI: 10.1016/S1872-2067(17)62885-7 | http://www.sciencedirect.com/science/journal/18722067 | Chin. J. Catal., Vol. 38, No. 10, October 2017 
improved by introducing a zeolitic-imidazolate framework. Polyaniline was used as a nitrogen precursor by $\mathrm{Wu}$ et al. [27], by heat-treating this compound in the presence of a transition metal and a carbon support to obtain a product, which exhibited superior activity and stability as well as excellent four-electron selectivity. Pyrrole has also been investigated as a nitrogen precursor during the thermal synthesis of a nitrogen doped Fe-N/C-TsOH ( $\rho$-toluenesulfonic acid) electrocatalyst that demonstrated high ORR catalytic activity and four-electron selectivity in an alkaline solution [28]. Chao et al. [29] synthesized a Co-N-C catalyst using an octahedral Co(II) complex with 2,6-bis(benzimidazole-2-yl)pyridine as the precursor. This $\mathrm{Co} / \mathrm{N}-\mathrm{HCOs}$ catalyst demonstrated a unique hollowed-out octahedral structure, which resulted in a large specific surface area and suitable pore structure, and thus led to better catalytic activity and superior stability compared with a commercial $\mathrm{Pt} / \mathrm{C}$ catalyst in alkaline solution. Unni et al. [30] investigated melamine as a nitrogen precursor to prepare an electrocatalyst via doping with $\mathrm{Fe}$ and $\mathrm{N}$ at $900{ }^{\circ} \mathrm{C}$. The resulting $\mathrm{Fe}-\mathrm{N}$-single-walled carbon nanohorns showed a positive shift of $30 \mathrm{mV}$ in onset potential and $20 \mathrm{mV}$ in half-wave potential compared with Pt/C. Later, Yan et al. [31] constructed nitrogen-doped graphene hollow microspheres (NGHMs) using graphene oxide nanosheets (GONs) as carbon supports in conjunction with the pyrolysis of melamine and GON-wrapped polystyrene microspheres under a nitrogen atmosphere. The limiting current density of the resulting NGHMs was comparable to that of $40 \mathrm{wt} \% \mathrm{Pt} / \mathrm{C}$ sourced from the Johnson Matthey company, and the material exhibited excellent stability, attributed to its high nitrogen content and hollow sphere architecture.

Using nanodiamonds, melamine, boric acid and $\mathrm{FeCl}_{3}$ as precursors, Liu et al. [32] synthesized a boron and nitrogen co-doped graphitic carbon/nanodiamond (BN-C/ND) catalyst through a simple one-step heat-treatment. The resulting material had a shell/core structure and exhibited high ORR activity in alkaline media in addition to enhanced electrochemical stability. Jiang et al. [33] prepared a highly active Fe-N-C ORR catalyst (Fe@C-FeNC) from carbon nanotubes, melamine and iron nitrate anhydrate. The catalyst contained $\mathrm{Fe}-\mathrm{N}_{x}$ bonds and graphene-encapsulated $\mathrm{Fe} / \mathrm{Fe}_{3} \mathrm{C}$ (Fe@C) nanocrystals. A half-wave potential of $0.899 \mathrm{~V}$ was observed and $15 \mathrm{mV}$ more positive than that of $\mathrm{Pt} / \mathrm{C}$. A template method was later used by Lee et al. [34] to synthesize $\mathrm{M}-\mathrm{N}-\mathrm{C}$ catalysts ( $\mathrm{M}=\mathrm{Fe}, \mathrm{Co}$ ), in which metal phthalocyanines, including FePc, CoPc and FeCoPc, were employed as the metal, nitrogen and carbon sources. Compared with commercial Pt/C, the FeCoPc-C exhibited a higher half-wave potential and a greater current density at 0.8 $\mathrm{V}$, as a result of its large specific surface area and high metal and nitrogen species doping levels.

Most of the above M-N-C catalysts exhibited excellent ORR activities and stabilities that approached or even exceeded those of Pt-based catalysts. However, the high cost of the nitrogen precursors (macrocyclic compounds that are less expensive than precious metals but still not inexpensive), the complicated preparation processes (such as those using aniline or pyrrole, which require strong oxidants and long polymeriza-<smiles>Cc1cc2nc3c(=O)[nH]c(=O)nc-3n(C[C@H](O)[C@H](O)[C@H](O)CO)c2cc1C</smiles>

Fig. 1. Molecular structure of riboflavin.

tion times), or the toxicity of the nitrogen sources (such as $\mathrm{NH}_{3}$ and aniline) still hinder the commercialization of NMPCs.

The present work investigated the use of riboflavin (Vitamin B2, VB2, Fig. 1), which has the advantages of low cost, minimal toxicity, valid graphitic nitrogen, high N/C ratio and no need of polymerization process. This compound was applied, for the first time as both the carbon and nitrogen precursor to synthesize an ORR catalyst via one-step pyrolysis in the presence of anhydrous ferric chloride. The physicochemical properties and morphologies of the resulting catalyst were characterized and its electrochemical performance in alkaline media was assessed.

\section{Experimental}

\subsection{Preparation of the $\mathrm{Fe}-\mathrm{N}-\mathrm{C}$ catalysts}

The catalysts, denoted as $\mathrm{Fe}-\mathrm{N}-\mathrm{C}-X$ where $X=W_{\mathrm{Fe}} /\left(W_{\mathrm{Fe}}+\right.$ $\left.W_{\mathrm{VB} 2}\right) \times 100 \%$, with $W$ being the precursor mass, were synthesized by one-step pyrolysis using riboflavin as the nitrogen and carbon precursor and ferric chloride as the transition metal precursor. In a typical synthesis, $1 \mathrm{~g}$ of riboflavin (Kelong Company, Chengdu, Sichuan, China, BR) was dispersed in ethanol, after that the transition metal precursor $\left(\mathrm{FeCl}_{3}\right.$, Shanpu Company, Shanghai, China, AR) was added. The resulting suspension was dried at $80{ }^{\circ} \mathrm{C}$ and then heated at a rate of $5{ }^{\circ} \mathrm{C}$ $\mathrm{min}^{-1}$ to $800{ }^{\circ} \mathrm{C}$ and maintained at that temperature for $2 \mathrm{~h}$ under an argon flow. The resulting product was refluxed in 0.5 mol L-1 $\mathrm{HCl}$ at $80^{\circ} \mathrm{C}$ for $4 \mathrm{~h}$, then washed with deionized water and dried at $70{ }^{\circ} \mathrm{C}$ overnight in a vacuum oven.

\subsection{Physical characterization}

Thermogravimetric analysis (TGA) of the $\mathrm{VB} 2 / \mathrm{FeCl}_{3}$ mixtures was carried out using a SDTA851e instrument between room temperature and $1000{ }^{\circ} \mathrm{C}$ in a $\mathrm{N}_{2}$ atmosphere at a heating rate of $10{ }^{\circ} \mathrm{C} \mathrm{min}^{-1}$. The functional groups present in the riboflavin as well in the catalysts were identified by Fourier transform infrared (FTIR) spectroscopy with a Nicolet 6700 spectrometer. Raman spectra were obtained with a Renishaw inVia spectrometer using incident laser light at $514.5 \mathrm{~nm}$. Nitrogen adsorption-desorption isotherms were acquired with a Quadrasorb SI instrument. The morphologies of the catalysts were observed using a Libra 200FE transmission electron microscope (TEM; Carl Zeiss SMT Pte., Ltd.) operated at 200 kV. X-ray diffraction (XRD) patterns were acquired with an X'Pert Pro MPD diffractometer using $\mathrm{Cu} K_{\alpha}$ radiation. X-ray photoelectron spectroscopy (XPS) data were acquired with a Thermo Scien- 
tific ESCALAB 250Xi X-ray photoelectron spectrometer using an $\mathrm{Al}-K_{\alpha}$ source.

\subsection{Electrochemical characterization}

The catalyst samples were made into inks by adding $25 \mu \mathrm{L}$ of a Nafion ${ }^{\circledR}$ solution ( $5 \mathrm{wt} \%$, Du Pont) to $1 \mathrm{~mL}$ of ethanol with ultrasonication for $15 \mathrm{~min}$. Following this, $5 \mathrm{mg}$ of catalyst powder was added with further ultrasonication for another $1 \mathrm{~h}$ to obtain a homogeneous ink. Finally, $48 \mu \mathrm{L}$ of the ink was dropped onto a glassy carbon (GC) disk to form a uniform film at a catalyst loading of $1.2 \mathrm{mg} \mathrm{cm}^{-2}$.

The ORR activity and stability of each catalyst was evaluated by linear sweep voltammetry (LSV) and by chronoamperometric $(i-t)$ response data acquired using an AutoLab Potentiostat 302N (Metrohm, Holland) in a three-electrode system at room temperature. A GC disk with an area of $0.196 \mathrm{~cm}^{2}$ and Pt wire were used as the working and counter electrode, respectively. $\mathrm{A} \mathrm{Hg} / \mathrm{HgO}$ electrode was used as the reference electrode in the alkaline electrolyte, while a $\mathrm{Ag} / \mathrm{AgCl}$ electrode was used as the reference electrode in the acid electrolyte. In this paper, all potentials are reported relative to a reference hydrogen electrode (RHE) using the following equations [35].

$$
\begin{aligned}
& E_{v s} \mathrm{RHE}=E_{v s \mathrm{Hg} / \mathrm{HgO}}+0.095+0.059 P H \\
& E_{v s \mathrm{RHE}}=E_{v s \mathrm{Ag} / \mathrm{AgCl}}+0.197+0.059 P H
\end{aligned}
$$

When investigating the ORR activities of the catalysts in the alkaline electrolyte, the polarization plots were recorded in an oxygen-saturated $0.1 \mathrm{~mol} \mathrm{~L}^{-1} \mathrm{KOH}$, with a potential step of 0.03 $\mathrm{V}$ from 0.16 to $1.16 \mathrm{~V}$ vs RHE, using a rotating disk electrode (RDE) at $1600 \mathrm{r} \mathrm{min}^{-1}$. Prior to RDE tests, the electrocatalyst was swept for several cycles between 0.16 and $1.16 \mathrm{~V}$ at $50 \mathrm{mV}$ $\mathrm{s}^{-1}$ in argon-saturated $0.1 \mathrm{~mol} \mathrm{~L}^{-1} \mathrm{KOH}$.

In the case of the acidic electrolyte, the polarization plots were recorded in an oxygen-saturated $0.5 \mathrm{~mol} \mathrm{~L}^{-1} \mathrm{H}_{2} \mathrm{SO}_{4}$, with a potential step of $0.03 \mathrm{~V}$ from 0 to $1 \mathrm{~V} v s$ RHE, again using an
$\mathrm{RDE}$ at $1600 \mathrm{r} \mathrm{min}^{-1}$. Before these trials, the electrocatalyst was swept for several cycles between 0 and $1 \mathrm{~V}$ at $50 \mathrm{mV} \mathrm{s}^{-1}$ in an argon-saturated $0.5 \mathrm{~mol} \mathrm{~L}^{-1} \mathrm{H}_{2} \mathrm{SO}_{4}$.

For comparison, the electrochemical performance of a commercial $40 \mathrm{wt} \% \mathrm{Pt} / \mathrm{C}$ catalyst (Johnson Matthey) with a loading of $0.2 \mathrm{mgt}_{\mathrm{Pt}} \mathrm{cm}^{-2}$ was also assessed.

\section{Results and discussion}

\subsection{TGA results}

Fig. 2(a) summarizes the mass loss of a $\mathrm{VB} 2 / \mathrm{FeCl}_{3}$ mixture with increasing temperature, as determined by TG analysis and DTG analysis. From these data, four steps can be identified in the VB2 pyrolysis process. The first starts at $25^{\circ} \mathrm{C}$ and reaches a plateau at ca. $120{ }^{\circ} \mathrm{C}$, with an associated mass loss of $3 \%$, and can be assigned to the volatilization of absorbed water [36]. The second step, from 120 to $310{ }^{\circ} \mathrm{C}$ with a mass loss of $20 \%$ is related to the elimination of three water molecules from the side-chain, leading to the formation of a series of conjugated double bonds, while the third step at approximately $350{ }^{\circ} \mathrm{C}$ is attributed to the release of this conjugated side chain from the parent molecule [37]. The resulting isoalloxazine is carbonized in the presence of $\mathrm{FeCl}_{3}$ as the temperature is further increased. The fourth step at approximately $800{ }^{\circ} \mathrm{C}$ likely involves the incorporation of nitrogen into the graphitized carbon, producing a nitrogen-doped carbon residue. The proposed reactions of the $\mathrm{VB} 2 / \mathrm{FeCl}_{3}$ mixture during heating are summarized in Fig. 2(b).

\subsection{FTIR and Raman results}

FTIR spectroscopy was used to investigate changes in the riboflavin structure during the heat-treatment. The spectra of riboflavin and of the $\mathrm{Fe}-\mathrm{N}-\mathrm{C}-7$ catalyst are presented in Fig.
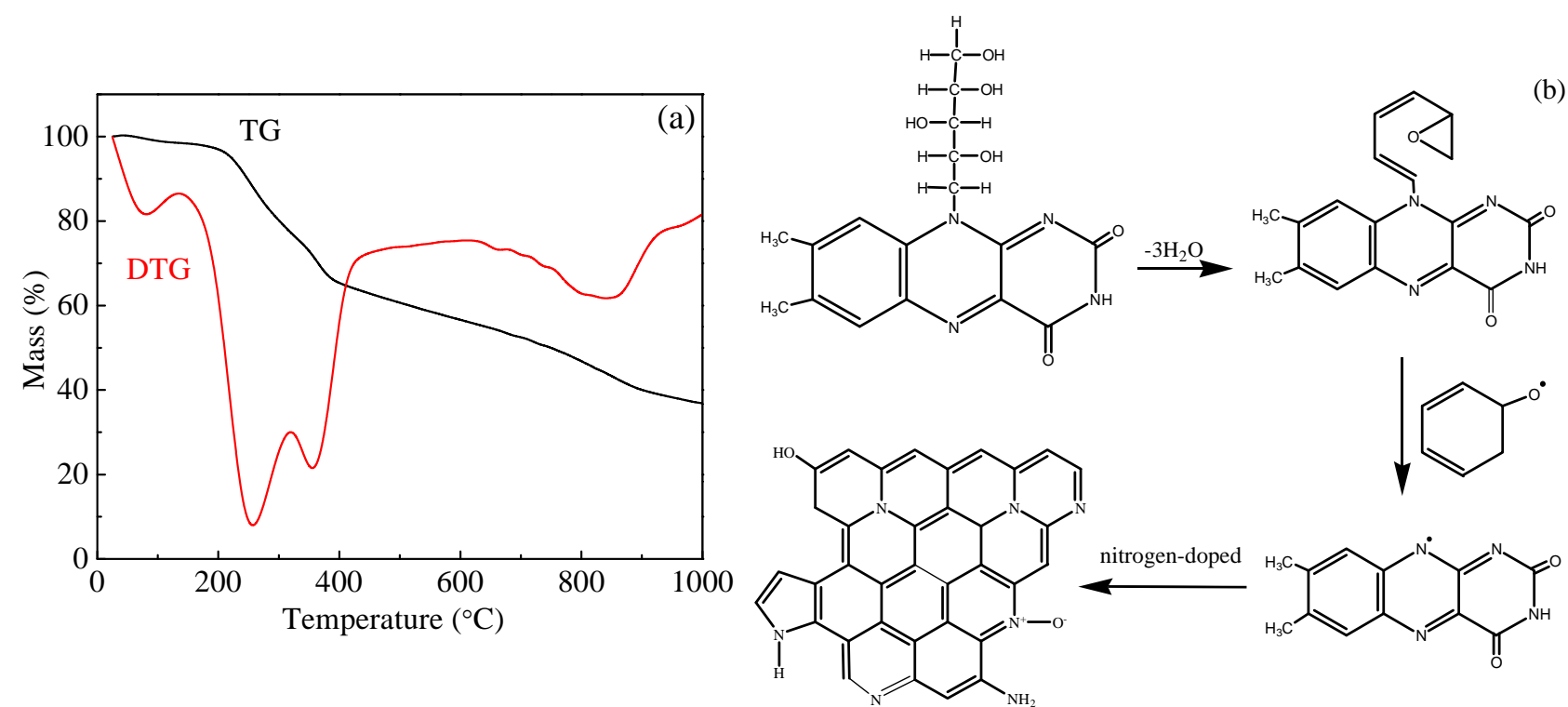

Fig. 2. (a) TG and DTG plots obtained from a VB2 $/ \mathrm{FeCl}_{3}$ mixture in a $\mathrm{N}_{2}$ atmosphere at a heating rate of $10{ }^{\circ} \mathrm{C}$ min ${ }^{-1}$; (b) Proposed reaction series for the pyrolysis of riboflavin. 

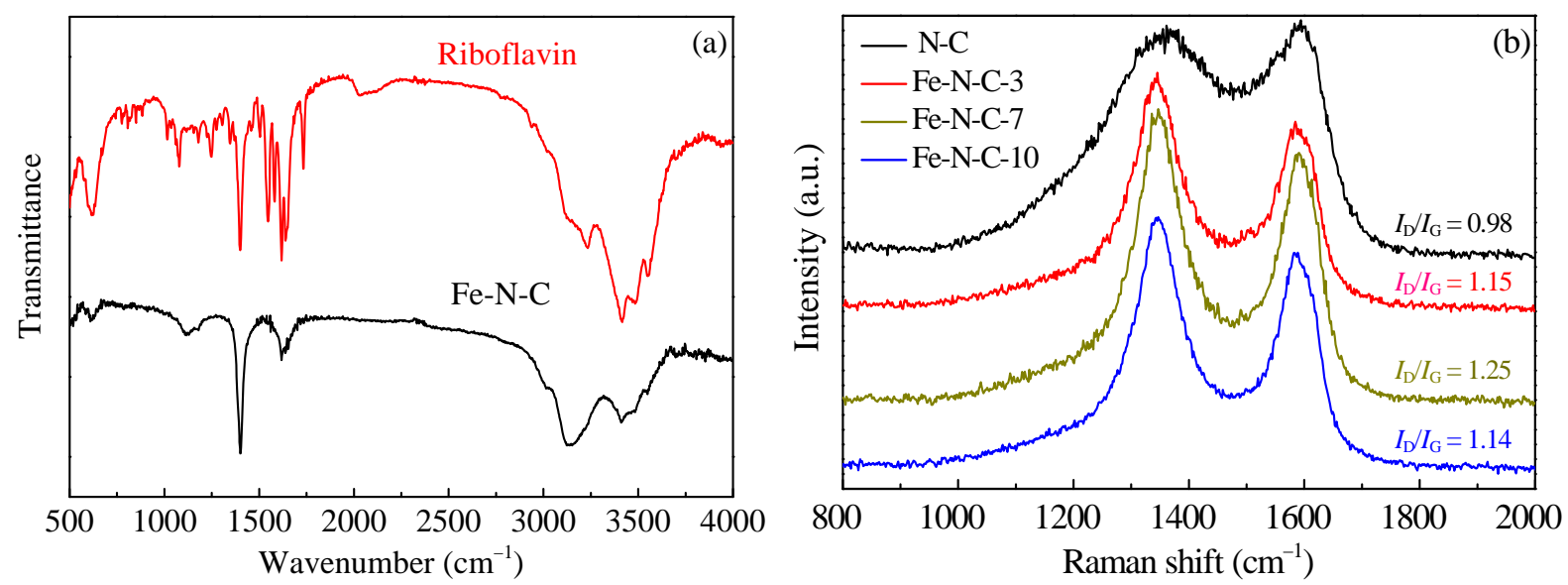

Fig. 3. (a) FTIR spectra of riboflavin and the Fe-N-C-7 catalyst; (b) Raman spectra of catalysts prepared with different nominal Fe contents.

3(a). A C-0 stretching peak is evident in the region 1071-1065 $\mathrm{cm}^{-1}$ for both samples. Consistent with the TGA results, an $\mathrm{O}-\mathrm{H}$ bending peak appears at $1220 \mathrm{~cm}^{-1}$ in the FTIR spectrum of riboflavin but disappears after heating, which is related to the elimination of water from the side-chain. The band at 1403 $\mathrm{cm}^{-1}$ in both the riboflavin and $\mathrm{Fe}-\mathrm{N}-\mathrm{C}-7$ catalyst spectra is assigned to the $\mathrm{C}-\mathrm{N}$ stretching vibration of the amide groups [38]. After the heat-treatment, the aryl $\mathrm{H}$ stretching peak at $1550 \mathrm{~cm}^{-1}$ and the amide $\mathrm{C}=0$ stretching peak at $1730 \mathrm{~cm}^{-1}$ both disappear as a consequence of the carbonization of the riboflavin. Furthermore, a medium intensity peak attributed to the $\mathrm{C}=\mathrm{N}-$ stretching vibration is evident at $1620 \mathrm{~cm}^{-1}$ [39] and a broad, high intensity band is observed in the vicinity of 3400 $\mathrm{cm}^{-1}$, demonstrating the presence of adsorbed water.

The chemical structures and structural defects of the catalysts were investigated by Raman spectroscopy, and the Raman spectra of catalysts prepared with different nominal Fe levels are shown in Fig. 3(b). The G band at approximately $1586 \mathrm{~cm}^{-1}$ is associated with the crystallinity of graphitic phases, while the D band at approximately $1351 \mathrm{~cm}^{-1}$ corresponds to defects in the carbon phase. The Fe-N-C-7 catalyst shows a relatively high $I_{\mathrm{D}} / I_{\mathrm{G}}$ ratio of 1.25 compared with those of the $\mathrm{N}-\mathrm{C}(0.98)$, $\mathrm{Fe}-\mathrm{N}-\mathrm{C}-3$ (1.15) and Fe-N-C-10 (1.14) catalysts, indicating a greater number of defects caused by doping with nitrogen, resulting in more ORR active sites.

\section{3. $N_{2}$ adsorption-desorption and pore-size distribution}

The specific surface area of the Fe-N-C-7 catalyst was determined from nitrogen adsorption-desorption isotherms, as shown in Fig. 4(a), and the resulting pore size distribution is presented in Fig. 4(b). The isotherm is a typical type IV curve, indicating that the catalyst was a mesoporous material. From Fig. 4(b), it can be seen that the pore size distribution was centered at $45 \mathrm{~nm}$. The specific surface area was determined to be $301 \mathrm{~m}^{2} \mathrm{~g}^{-1}$ using the Brunauer-Emmett-Teller (BET) method. This high specific surface area would be expected to provide an adequately electrochemical active region and the mesoporous pore size should facilitate mass transport, both of which will tend to improve the electrochemical performance of the material.

\subsection{TEM result}

The morphology of the catalyst was observed by TEM, as shown in Fig. 5, which demonstrates the sponge-like structure
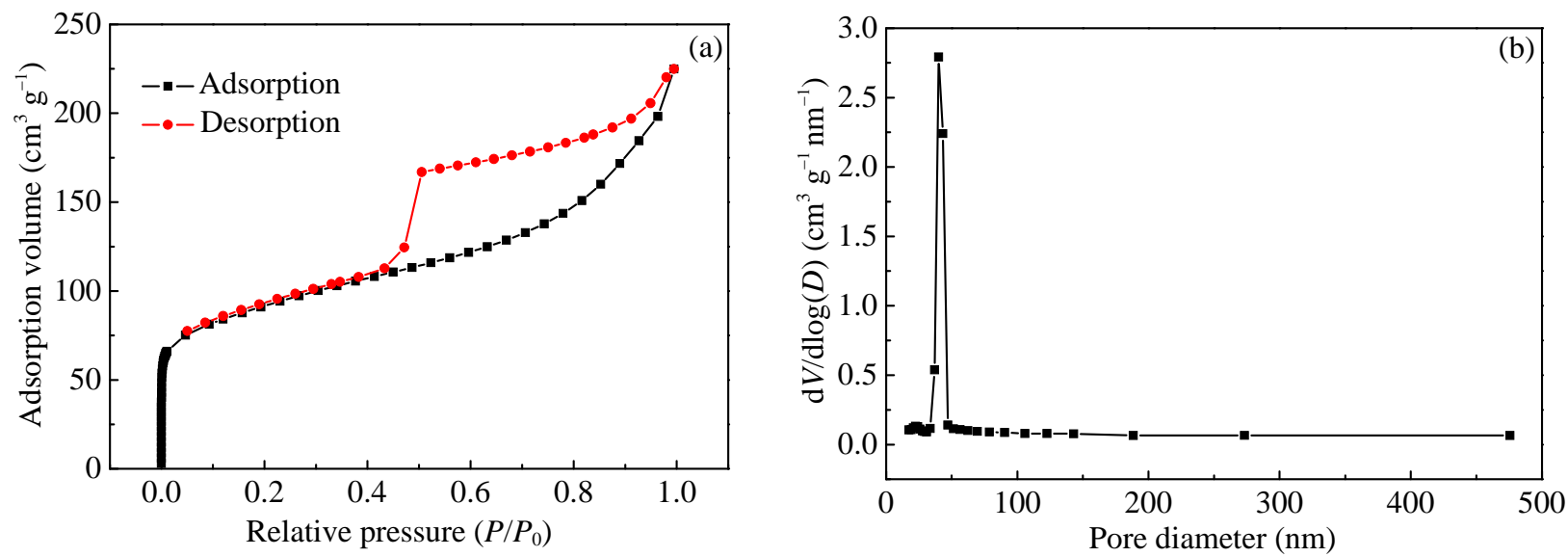

Fig. 4. $\mathrm{N}_{2}$ adsorption-desorption isotherm (a) and the pore size distribution (b) of the Fe-N-C-7 catalyst. 


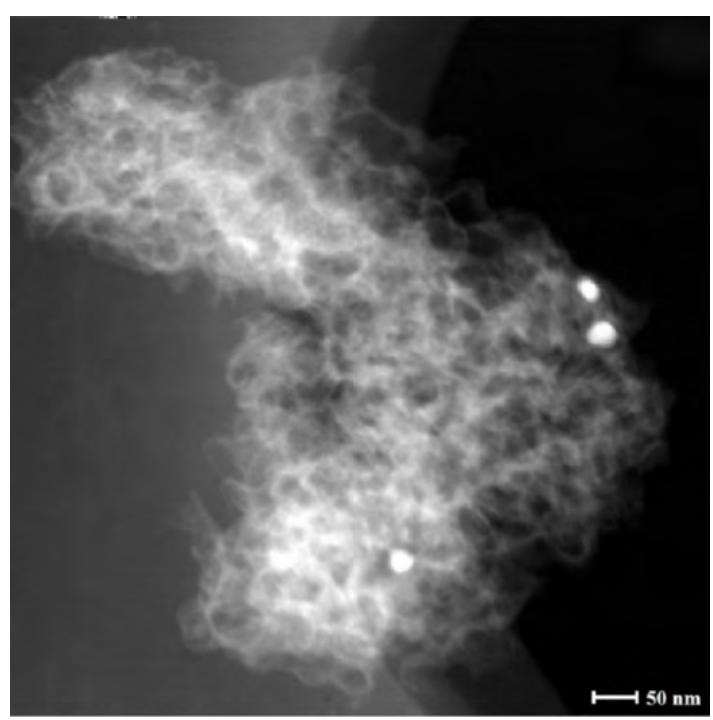

Fig. 5. TEM image of the Fe-N-C-7 catalyst prepared using riboflavin.

of this material. Two phases are evident. One is a loose, white, cloud-like phase, representing the VB2 pyrolysis product and consisting of very thin, curved, and porous carbon materials similar to graphene sheets. This phase was further characterized by XRD analysis. The other regions in this image represent $\mathrm{Fe}_{2} \mathrm{O}_{3}$ nanoparticles that encapsulated in the aforementioned carbon material and so not removed during the $\mathrm{HCl}$ leaching process.

\subsection{XRD analysis}

The XRD pattern of the Fe-N-C-7 catalyst and standard graphite carbon and $\mathrm{Fe}_{2} \mathrm{O}_{3}$ patterns are shown in Fig. 6. The diffraction peaks at $26^{\circ}$ and $43^{\circ}$ are characteristic of the (002) and (101) planes of graphitized carbon, and the strong, sharp (002) peak indicates that the carbon materials in the Fe-N-C-7 catalyst were highly graphitized [40]. Combined with the TEM image, these data demonstrate that the carbon was in the form

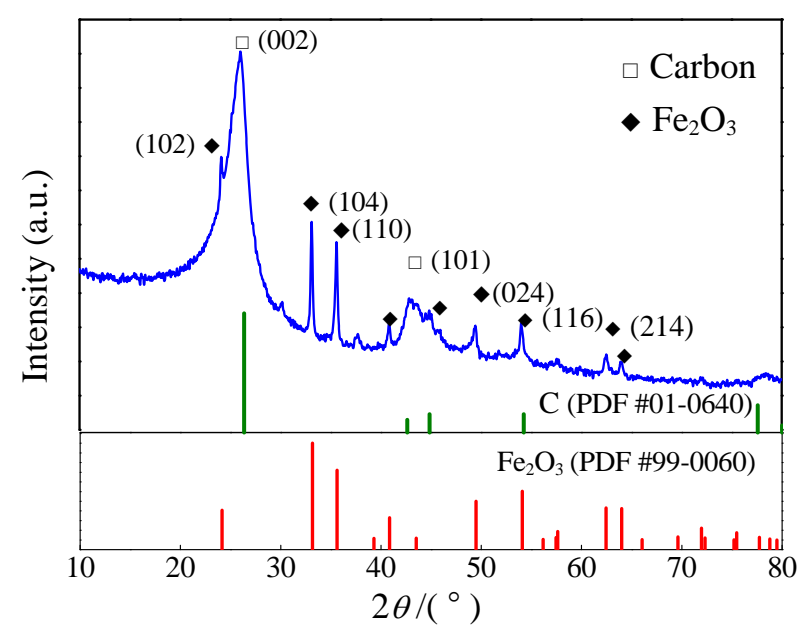

Fig. 6. XRD patterns of the Fe-N-C-7 catalyst, standard graphite carbon and $\mathrm{Fe}_{2} \mathrm{O}_{3}$. of curved graphene sheets. This unique structure is expected to assist in promoting the ORR. The remaining diffraction peaks at $24.1^{\circ}, 33.1^{\circ}, 35.6^{\circ}, 49.4^{\circ}, 54.0^{\circ}$ and $62.4^{\circ}$ are in accordance with the (102), (104), (110), (024), (116) and (214) planes of $\mathrm{Fe}_{2} \mathrm{O}_{3}$, and so can be attributed to $\mathrm{Fe}_{2} \mathrm{O}_{3}$ nanoparticles generated from $\mathrm{FeCl}_{3}$ during the mixing and heat-treatment processes [41]. These $\mathrm{Fe}_{2} \mathrm{O}_{3}$ particles must have been encapsulated by the graphitized carbon, because they were not removed by acid leaching.

\section{6. $X P S$}

The composition and element binding energies of the Fe-N-C catalysts synthesized by addition of varying amounts of Fe precursor were analyzed by XPS. As shown in Fig. 7(a), the XPS survey spectra confirmed that all the catalysts consisted of carbon (C $1 s=290 \mathrm{eV})$, nitrogen (N $1 s=400 \mathrm{eV})$, oxygen (O $1 s$ $=532 \mathrm{eV}$ ), and traces of iron (Fe $2 p=720 \mathrm{eV})$. The predominant $C 1 s$ peak appears at a binding energy of $290.0 \mathrm{eV}$, which is higher than the $284.5 \mathrm{eV}$ carbon black peak, and this result can be partly attributed to the doping of nitrogen atoms into the carbon matrix. The higher electronegativity of nitrogen will affect the charge density of adjacent carbon atoms, which may be advantageous to the absorption of oxygen molecules and further enhance catalysis of the ORR. The proportions of these four elements are provided in Table 1 . It can be seen that the concentrations of these elements decreased in the order of $\mathrm{C}>$ $\mathrm{O}>\mathrm{N}>\mathrm{Fe}$. At a nominal Fe concentration of $7 \mathrm{wt} \%$, the $\mathrm{N}$ content reached its maximum, which may also have contributed to increasing the ORR activity of this material. High-resolution Fe $2 p$ spectra are shown in Fig. 7(b)-(d). It can be clearly seen that Fe $2 p_{3 / 2}(\sim 710.2 \mathrm{eV})$ and Fe $2 p_{1 / 2}(\sim 723.0 \mathrm{eV})$ peaks are present along with two satellites $(\sim 715.2$ and $\sim 729.0 \mathrm{eV})$, all attributable to $\mathrm{Fe}^{3+}$. These ions were presumably in the form of $\mathrm{Fe}_{2} \mathrm{O}_{3}$ (corresponding to the XRD pattern). In addition, the $\mathrm{Fe}$ levels increase with increasing amounts of the initial Fe precursor. However, Table 1 also shows that only small amounts of Fe were contained in these materials, implying that Fe was present primarily in the form of $\mathrm{Fe}_{2} \mathrm{O}_{3}$ and was removed during acid leaching, and so only a trace of Fe was involved in the formation of $\mathrm{Fe}-\mathrm{N}_{x}$ and/or $\mathrm{CN}_{x}$.

The chemical environment of an element will affect its binding energy. In the case of nitrogen-doped carbon materials, there are four types of nitrogen that can be considered, each with its own binding energy. These are pyridinic, pyrrolic, graphitic and oxidized nitrogen with binding energies of approximately 398.5, 399.9, 401.2 and $403.3 \mathrm{eV}$. Here, pyridinic, graphitic and pyrrolic nitrogen refer to nitrogen atoms doped at the edges of graphitic carbon layers with two adjacent carbon atoms, doped inside a graphitic carbon basal layer, and in a pentagon structure that contribute two $p$ electrons to the $\pi$ system, respectively. It is commonly held that oxidized nitrogen does not contribute to the ORR activity and that the total amount of nitrogen is not linked to ORR activity. Whether pyrrolic nitrogen affecting this activity or not is still in dispute. Therefore, pyridinic and graphitic nitrogen are assumed to be the main active sites for the ORR, although it is still not clear 

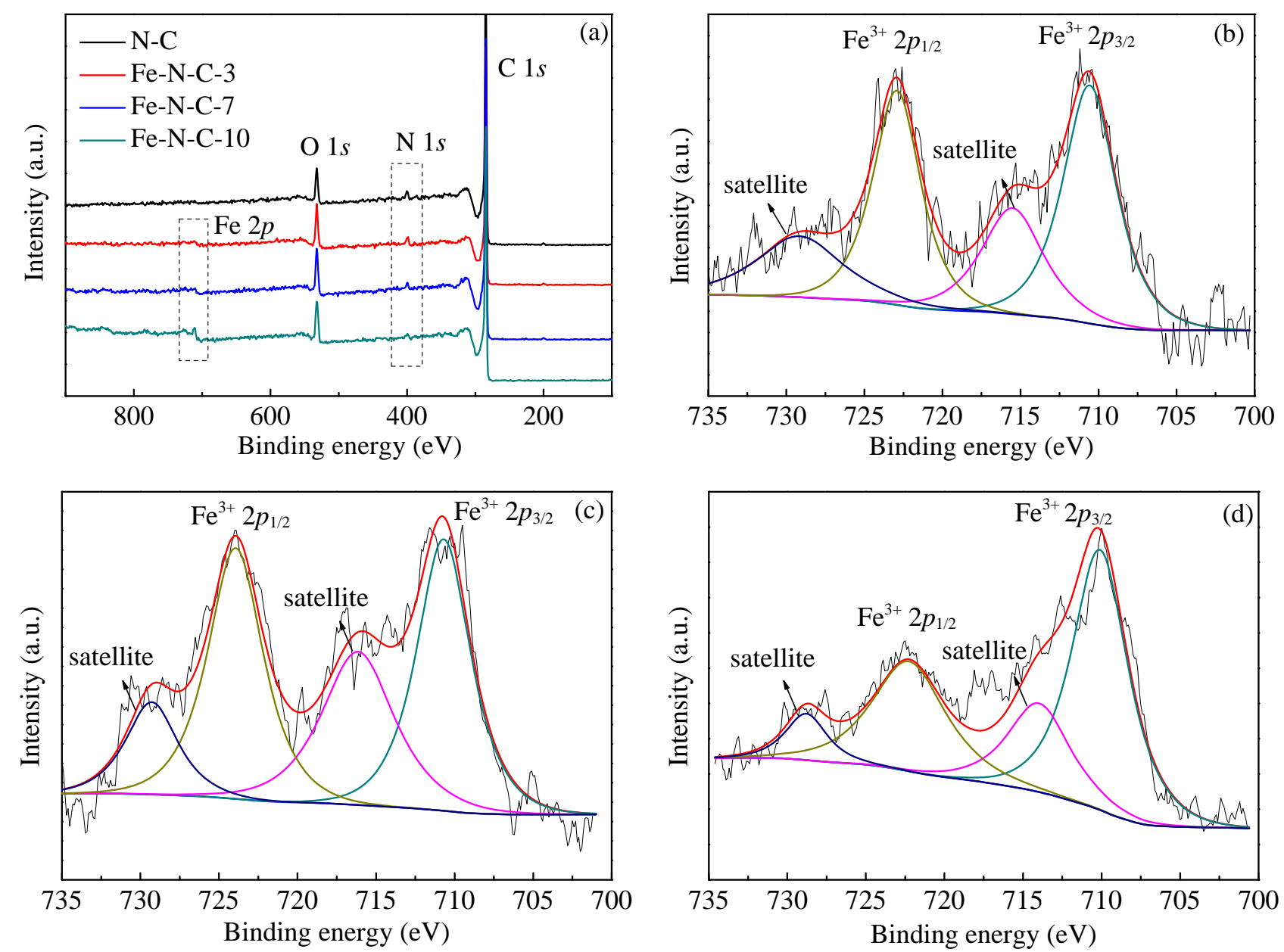

Fig. 7. XPS survey spectra (a) and high-resolution Fe $2 p$ XPS spectra of $\mathrm{Fe}-\mathrm{N}-\mathrm{C}-3$ (b), $\mathrm{Fe}-\mathrm{N}-\mathrm{C}-7$ (c), and Fe-N-C-10 (d) catalysts.

which one is predominant [42]. To further assess the roles of these different types of nitrogen in forming active sites and thus affecting the ORR performance, high-resolution $\mathrm{N} 1 s \mathrm{XPS}$ spectra of the as-prepared catalysts were acquired and are displayed in Fig. 8(a)-(d). Four types of nitrogen peaks can be fitted: pyridinic (N1), pyrrolic (N2), graphitic (N3), and oxidized nitrogen (N4). The proportions of these four types of nitrogen in the various catalyst samples are summarized in Table 2 .

In the case of VB2 pyrolysis without Fe, the proportions of pyridinic, pyrrolic, graphitic and oxidized nitrogen were 0.336 , $0.219,0.324$ and 0.121 , respectively. Upon adding Fe to the VB2 prior to pyrolysis, the pyridinic nitrogen concentration remains almost constant at nominal Fe levels of 3 and $7 \mathrm{wt} \%$, then decreases slightly at $10 \mathrm{wt} \% \mathrm{Fe}$. In the case of pyrrolic nitrogen,

\section{Table 1}

Concentrations of various elements in the catalysts prepared with different $\mathrm{Fe}$ amounts (at \%).

\begin{tabular}{lcccc}
\hline Catalyst & $\mathrm{C}$ & $\mathrm{N}$ & 0 & $\mathrm{Fe}$ \\
\hline Fe-N-C-3 & 93.1 & 1.6 & 4.9 & 0.4 \\
Fe-N-C-7 & 91.5 & 1.9 & 6.0 & 0.6 \\
Fe-N-C-10 & 92.7 & 1.1 & 5.5 & 0.7 \\
\hline
\end{tabular}

equivalent amounts are obtained with 3 and $10 \mathrm{wt} \% \mathrm{Fe}$, but a minimum is observed at $7 \mathrm{wt} \% \mathrm{Fe}$. The graphitic nitrogen content decreases in the following order of Fe addition: $7 \mathrm{wt} \%>10$ $w t \%>3 \mathrm{wt} \%$. These results are consistent with the relative order of ORR activities, indicating that graphitic nitrogen makes the greatest contribution to active sites for the ORR. Because oxidized nitrogen does not contribute to the ORR activity, it is not considered here [43]. According to Lai et al. [44], the presence of graphitic nitrogen affects the limiting current density while pyridinic nitrogen is related to variations in the on-set potential. From Table 2, we can see that there were no significant differences in the pyridinic nitrogen levels between catalysts made with varying amounts of the Fe precursor, indicating that their on-set potentials should be approximate equal. This was confirmed by the LSV data in Fig. 9(a). Comparing the ORR activities of catalysts prepared with varying Fe contents, it appears that the pyrrolic nitrogen might exhibit some limited ability to promote the ORR. The types and concentrations of nitrogen species in the catalyst obtained from direct VB2 pyrolysis were similar to those of the $\mathrm{Fe}-\mathrm{N}-\mathrm{C}-7$ specimen. However, the ORR activities of the $\mathrm{N}-\mathrm{C}$ and $\mathrm{Fe}-\mathrm{N}-\mathrm{C}-7$ catalysts were very different. In the case of the catalyst obtained by VB2 pyrolysis without the addition of $\mathrm{Fe}$, we can be sure that nitrogen 

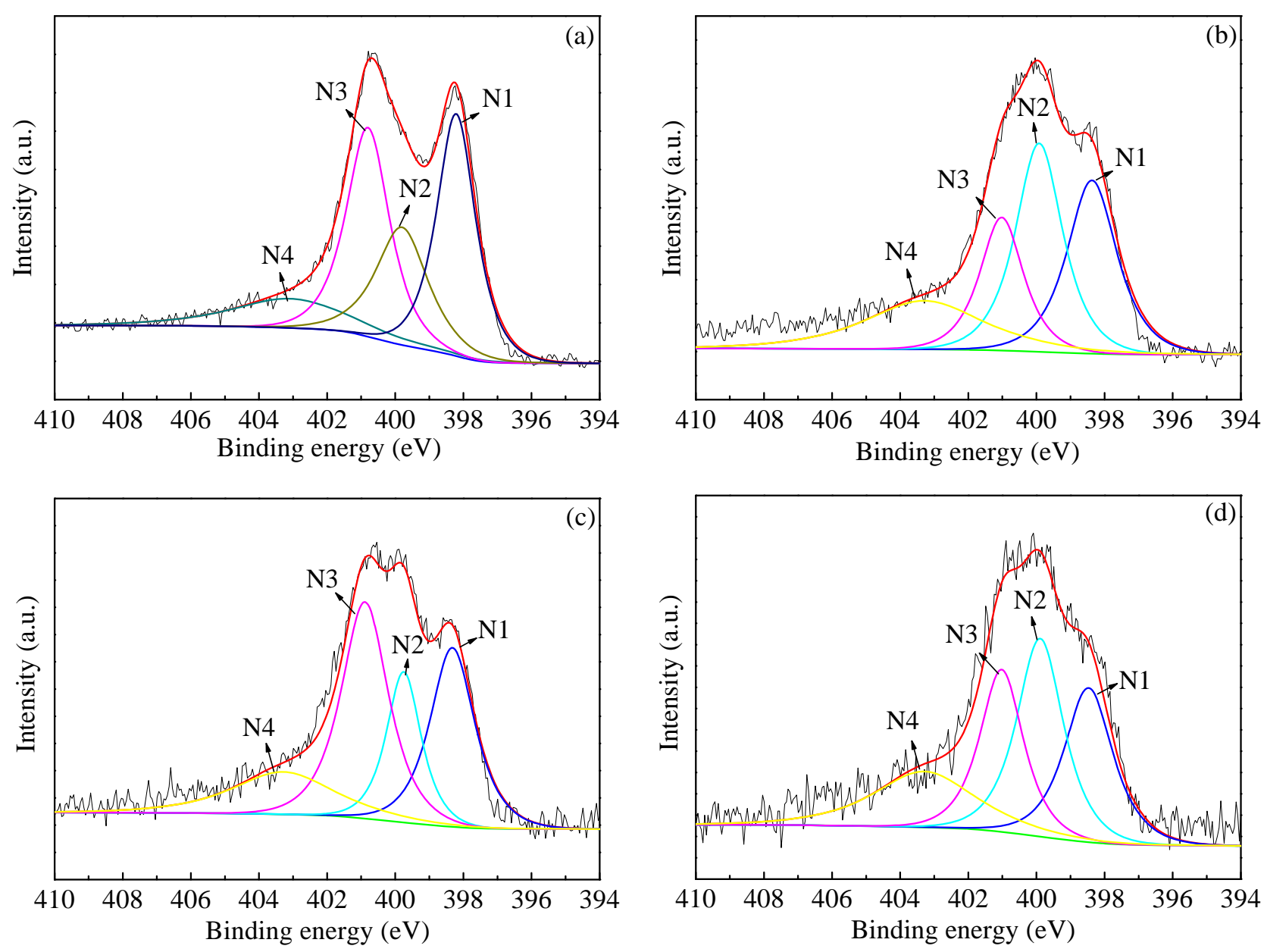

Fig. 8. High-resolution $\mathrm{N} 1 s$ XPS spectra of $\mathrm{N}-\mathrm{C}(\mathrm{a}), \mathrm{Fe}-\mathrm{N}-\mathrm{C}-3$ (b), Fe-N-C-7 (c), and Fe-N-C-10 (d) catalysts.

species definitely functioned as active sites for the ORR, because this material demonstrated ORR activity in the absence of $\mathrm{Fe}$, as shown in Fig. 9(a). However, the addition of the Fe precursor during VB2 pyrolysis resulted in $\mathrm{Fe}-\mathrm{N}-\mathrm{C}$ catalysts showing much better ORR activity. This result, combined with the XPS data, demonstrates that Fe not only plays an important role in the graphitization process but also serves to generate active ORR sites.

\subsection{ORR activities in an alkaline medium}

As noted, the present $\mathrm{Fe}-\mathrm{N}-\mathrm{C}$ catalyst was developed as a material that does not require precious metals to promote the ORR. The electrocatalytic ORR activities of Fe-N-C catalysts having different nominal $\mathrm{Fe}$ contents were therefore examined

Table 2

Proportions of various $\mathrm{N}$ species in the catalysts prepared using different amounts of $\mathrm{Fe}$ (at\%).

\begin{tabular}{lcccc}
\hline Catalyst & Pyridinic N & Pyrrolic N & Graphitic N & Oxidized N \\
\hline N-C & 33.6 & 21.9 & 32.4 & 12.1 \\
Fe-N-C-3 & 28.8 & 32.7 & 19.3 & 19.2 \\
Fe-N-C-7 & 28.9 & 18.8 & 36.7 & 15.6 \\
Fe-N-C-10 & 25.6 & 31.3 & 23.9 & 19.2 \\
\hline
\end{tabular}

by LSV. The ORR polarization curves for the $\mathrm{N}-\mathrm{C}, \mathrm{Fe}-\mathrm{N}-\mathrm{C}-3$, Fe-N-C-7 and Fe-N-C-10 specimens and for the commercial 40 wt $\% \mathrm{Pt} / \mathrm{C}$ in an $\mathrm{O}_{2}$-saturated $0.1 \mathrm{~mol} \mathrm{~L}^{-1} \mathrm{KOH}$ electrolyte are presented in Fig. 9(a).

The ORR activity initially increased with Fe content and then decreased, reaching a maximum at $7 \mathrm{wt} \% \mathrm{Fe}$, based on assessments of the on-set potential, limiting current density and half-wave potential. At $0.66 \mathrm{~V}$ vs RHE, the current densities were $-2.07,-2.53,-4.11$ and $-3.80 \mathrm{~mA} \mathrm{~cm}^{-2}$ for the $\mathrm{N}-\mathrm{C}$, $\mathrm{Fe}-\mathrm{N}-\mathrm{C}-3, \mathrm{Fe}-\mathrm{N}-\mathrm{C}-7$ and $\mathrm{Fe}-\mathrm{N}-\mathrm{C}-10$, respectively. Without the addition of the Fe precursor, the catalyst should only consist of nitrogen, carbon and oxygen, and yet the $\mathrm{N}-\mathrm{C}$ catalyst demonstrated ORR activity, suggesting that $\mathrm{N}$ and $\mathrm{C}$ species can separately form active sites for the ORR in the absence of Fe. After adding the Fe precursor, the ORR activity was increased. This effect may have resulted from that the formation of additional active sites composed of Fe species or from changes in the catalyst microstructure and/or composition that in turn promoted the ORR activity of the material. The pyridinic and pyrrolic nitrogen levels were higher in the $\mathrm{Fe}-\mathrm{N}-\mathrm{C}-3$ than in the Fe-N-C-10, while their oxidized nitrogen concentrations were equal, and the graphitic nitrogen concentration of the $\mathrm{Fe}-\mathrm{N}-\mathrm{C}-3$ was less than that of the Fe-N-C-10. As stated above, the ORR 

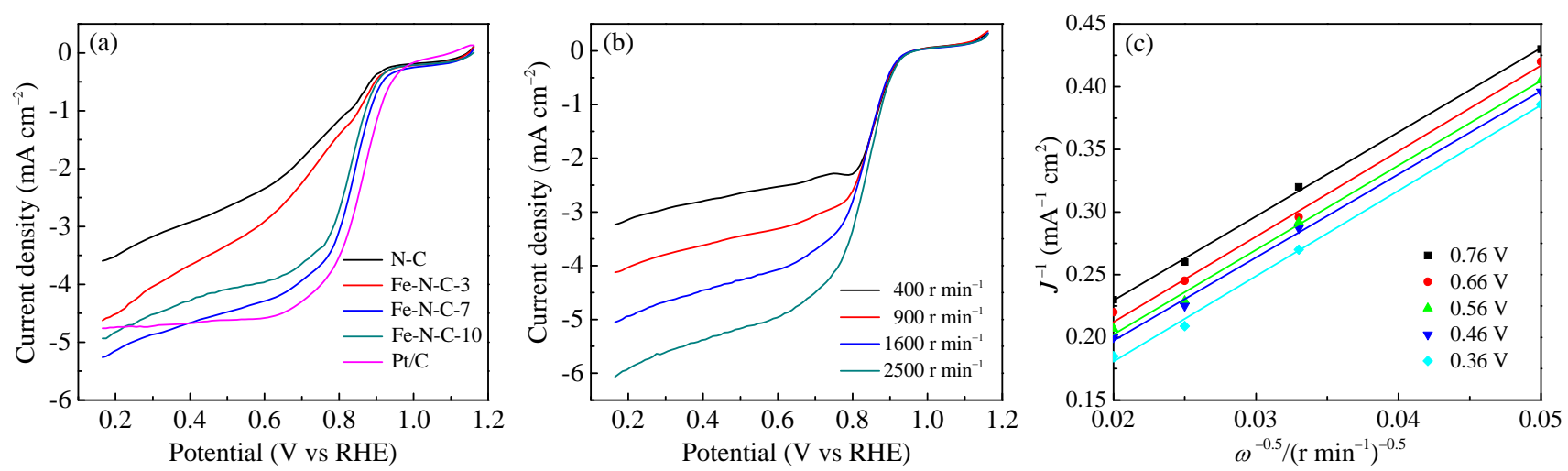

Fig. 9. (a) RDE polarization curves for catalysts with different Fe contents and commercial Pt/C in the $\mathrm{O}_{2}$-saturated $0.1 \mathrm{~mol} \mathrm{~L}^{-1} \mathrm{KOH}$ solution at a rotation rate of $1600 \mathrm{r} \mathrm{min}^{-1}$; (b) LSV curves of the Fe-N-C-7 catalyst at various electrode rotation rates; (c) Koutecky-Levich plots obtained from the Fe-N-C-7 catalyst at different potentials in the $\mathrm{O}_{2}$-saturated $0.1 \mathrm{~mol} \mathrm{~L}^{-1} \mathrm{KOH}$ solution.

activity of the Fe-N-C-3 catalyst was $-2.53 \mathrm{~mA} \mathrm{~cm}^{-2}$ at $0.66 \mathrm{~V} v \mathrm{~s}$ RHE, which was much lower than the value of $-3.80 \mathrm{~mA} \mathrm{~cm}-2$ obtained from the Fe-N-C-10. Considering the XPS analysis results together with the ORR activity data, it appears that the ORR activity is affected by the graphitic nitrogen concentration. Comparing the $\mathrm{Fe}-\mathrm{N}-\mathrm{C}-3$ and $\mathrm{Fe}-\mathrm{N}-\mathrm{C}-7$ catalysts, it might be concluded that the pyrrolic nitrogen is not very active during the ORR although it is difficult to determine the activity of pyrrolic nitrogen species. In summary, both $\mathrm{N}$ and $\mathrm{C}$ species are active for the ORR, while Fe-based species also play important roles, even though the associated mechanism is not yet clear. Compared with the Pt/C catalyst, the on-set potential and the limiting current density of the $\mathrm{Fe}-\mathrm{N}-\mathrm{C}-7$ were more positive, indicating an improved performance of this new material in an alkaline electrolyte and demonstrating that the $\mathrm{Fe}-\mathrm{N}-\mathrm{C}$ catalyst is a potential replacement for the more costly commercial $\mathrm{Pt} / \mathrm{C}$ catalyst in alkaline electrolytes.

\subsection{Electrochemical ORR mechanism}

The ORR is a very complex process, involving four-electron and two-electron transfer pathways whether in an acidic or alkaline electrolyte. Under alkaline conditions, oxygen is reduced to $\mathrm{OH}^{-}$in the presence of $\mathrm{H}_{2} \mathrm{O}$ by a four-electron pathway, as shown in Eq. (3), which promotes the ORR. However, a two-electron pathway is inevitable as a side reaction, which will decrease the efficiency of the ORR, as shown in Eq. (4).

$$
\begin{gathered}
\mathrm{O}_{2}+2 \mathrm{H}_{2} \mathrm{O}+4 \mathrm{e}^{-} \rightarrow 4 \mathrm{OH}^{-} \\
\mathrm{O}_{2}+\mathrm{H}_{2} \mathrm{O}+2 \mathrm{e}^{-} \rightarrow \mathrm{HO}_{2}^{-}+\mathrm{OH}^{-}
\end{gathered}
$$

To further investigate the kinetics of electrochemical catalytic ORR using the Fe-N-C-7 catalyst, LSV was performed at different rotation rates. The LSV curves acquired in the $\mathrm{O}_{2}$-saturated $0.1 \mathrm{~mol} \mathrm{~L}^{-1} \mathrm{KOH}$ solution are shown in Fig. 9(b). The current density evidently increased with rotation rate, which can be explained by a shortened diffusion distance at high rotation rates $[45,46]$. In addition, the corresponding Koutecky-Levich (K-L) plots of $J^{-1} v s \omega^{-1 / 2}$ at different potentials exhibit good linearity together with parallelism, as shown in Fig. 9(c). This result suggests that the ORR proceeds via first-order reaction kinetics [47]. The number of electrons transferred per $\mathrm{O}_{2}$ molecule can be calculated using Eqs. (5) and (6).

$$
\begin{gathered}
1 / J=1 / J_{\mathrm{L}}+1 / J_{\mathrm{K}}=1 /\left(B \cdot \omega^{1 / 2}\right)+1 / J_{\mathrm{K}} \\
B=0.2 \cdot n \cdot F \cdot\left(D_{0}\right)^{2 / 3} \cdot C_{0} \cdot v^{-1 / 6}
\end{gathered}
$$

Here, $J$ is the measured current density, $J_{\mathrm{K}}$ and $J_{\mathrm{L}}$ are the kinetic and diffusion-limiting current densities respectively, $\omega$ is the electrode rotation rate $\left(\mathrm{r} \min ^{-1}\right), B$ is related to the diffusion-limiting current density, $n$ is the number of electrons transferred per $\mathrm{O}_{2}$ molecule, $\mathrm{F}$ is the Faraday constant $(96485$ $\mathrm{C} / \mathrm{mol}$ ), $\mathrm{Do}_{2}$ is the oxygen diffusion coefficient, $v$ is the kinematic viscosity of the electrolyte, and $\mathrm{Co}_{2}$ is the concentration of $\mathrm{O}_{2}$ in the bulk. The constant value of 0.2 is adopted when the rotation rate is expressed in $r \mathrm{~min}^{-1}$. The electron transfer number $(n)$ as determined from the $K$ - $L$ slopes was 3.9 in 0.1 mol L-1 $\mathrm{KOH}$, and this value is close to that of the commercial $\mathrm{Pt} / \mathrm{C}$ catalyst (3.99), demonstrating that the $\mathrm{Fe}-\mathrm{N}-\mathrm{C}-7$ catalyst exhibits a dominant four-electron oxygen reduction pathway in an alkaline medium. The high on-set potential and the nearly four-electron value reflect the excellent ORR activity and selectivity of the $\mathrm{Fe}-\mathrm{N}-\mathrm{C}$ catalyst. Therefore, riboflavin shows a promising nitrogen precursor for synthesis of the ORR catalysts.

\subsection{ORR stability in an alkaline medium}

The stabilities of Fe-N-C-7 and Pt/C catalysts during the ORR were evaluated using LSV and chronoamperometric response $(i-t)$ data acquired in a $\mathrm{KOH}$ electrolyte $\left(0.1 \mathrm{~mol} \mathrm{~L}^{-1}\right)$. The LSV curves before and after $1000 \mathrm{CV}$ cycles are shown in Fig. 10(a) and (b). After 1000 cycles, the LSV data indicate only a $5 \mathrm{mV}$ loss in the half-wave potential for the Fe-N-C-7 catalyst but a $60 \mathrm{mV}$ loss in the case of the Pt/C catalyst. It is therefore obvious that the Fe-N-C-7 exhibits better stability in the alkaline electrolyte. The stabilities of the Fe-N-C-7 and commercial $\mathrm{Pt} / \mathrm{C}$ catalysts were also assessed based on their chronoamperometric responses at a constant voltage over $10800 \mathrm{~s}$ in the $\mathrm{O}_{2}$-saturated $0.1 \mathrm{~mol} \mathrm{~L}^{-1} \mathrm{KOH}$ solution at a rotation rate of 1600 $\mathrm{r}$ min $^{-1}$, as shown in Fig. 10(c). The Fe-N-C sample exhibited only minimal activity loss, retaining a high relative current density of $97 \%$ after 10800 s. In contrast, the commercial Pt/C 

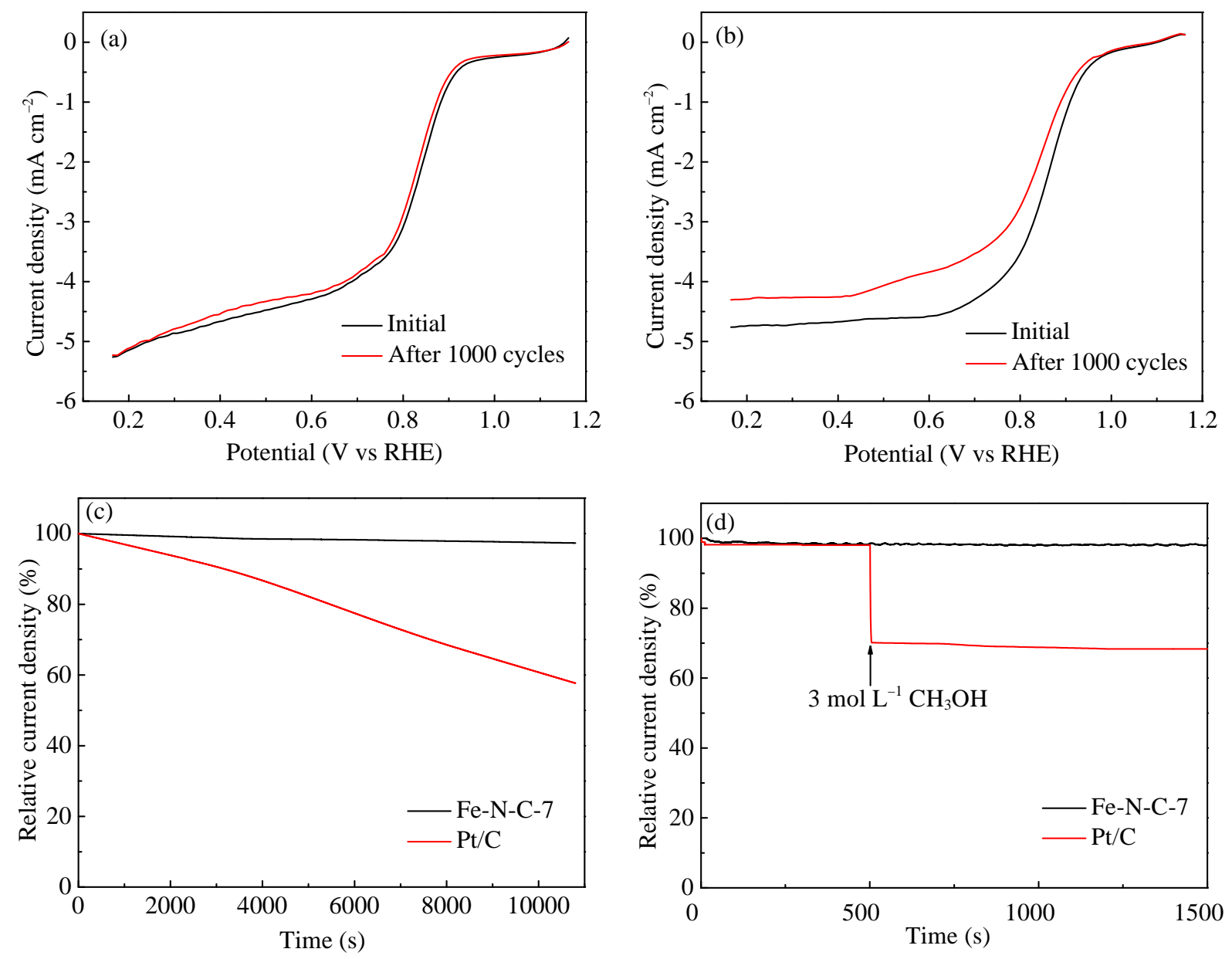

Fig. 10. ORR curves obtained from Fe-N-C-7 (a) and commercial Pt/C (b) catalysts before and after $1000 \mathrm{CV}$ cycles; chronoamperometric responses (c) and effects of methanol poisoning on the chronoamperometric responses (d) of the Fe- $\mathrm{N}-\mathrm{C}-7$ and Pt/C catalysts at $0.66 \mathrm{~V}$ ( $v s$ RHE) in an $\mathrm{O}_{2}$-saturated $0.1 \mathrm{~mol} \mathrm{~L}^{-1} \mathrm{KOH}$ solution.

catalyst lost nearly $40 \%$ of its initial activity, again indicating the superior stability of the Fe-N-C-7 catalyst. This improved stability of the Fe-N-C-7 catalyst can be attributed to its robust active sites. In addition, from Fig. 10(d), it can be seen that adding $1 \mathrm{~mL}$ of $3 \mathrm{~mol} \mathrm{~L}^{-1} \mathrm{CH}_{3} \mathrm{OH}$ into $100 \mathrm{~mL}$ electrolyte at 500 $\mathrm{s}$ leads to a sharp drop of $28 \%$ in the relative current density of the commercial Pt/C. Conversely, the Fe-N-C-7 does not exhibit a loss, indicating that this material has much better methanol tolerance.

\subsection{ORR activities and stability in an acidic medium}

As shown in Fig. 11(a), at $0.5 \mathrm{~V}$ vs RHE, the current densities were $-0.35,-1.96,-3.55$ and $-2.38 \mathrm{~mA} \mathrm{~cm}^{-2}$ for the $\mathrm{N}-\mathrm{C}$, $\mathrm{Fe}-\mathrm{N}-\mathrm{C}-3, \mathrm{Fe}-\mathrm{N}-\mathrm{C}-7$ and $\mathrm{Fe}-\mathrm{N}-\mathrm{C}-10$, respectively. Compared to the $\mathrm{Pt} / \mathrm{C}$ catalyst, the half-wave potential of the $\mathrm{Fe}-\mathrm{N}-\mathrm{C}-7$ is lower by $154 \mathrm{mV}$. Thus, the ORR activity of this material in an acidic medium will need to be improved in future research. The LSV curves before and after $1000 \mathrm{CV}$ cycles are shown in Fig. 11(b) and (c). After cycling, the half-wave potential of the $\mathrm{Fe}-\mathrm{N}-\mathrm{C}$ was reduced by $10 \mathrm{mV}$ compared to a loss of $25 \mathrm{mV}$ in the case of the $\mathrm{Pt} / \mathrm{C}$, demonstrating that the $\mathrm{Fe}-\mathrm{N}-\mathrm{C}-7$ exhibits better stability in the acidic electrolyte. Fig. 11(d) shows that the $\mathrm{Fe}-\mathrm{N}-\mathrm{C}$ catalyst undergoes only a slight loss of activity, retaining a high relative current density of $95 \%$ after $10,800 \mathrm{~s}$, while the Pt/C retains only $79 \%$ of its initial activity, again indicating superior stability of the Fe-N-C-7 catalyst in the acidic medium.

\section{Conclusions}

A series of efficient and cost-effective ORR catalysts was successfully synthesized through the pyrolysis of riboflavin in the presence of anhydrous iron chloride. Having a unique, cloud-like morphology, the catalysts demonstrate a high degree of ORR activity, remarkable stability and a dominant four-electron oxygen reduction pathway in alkaline media. XPS analysis and assessment of the ORR activities of catalysts with different $\mathrm{Fe}$ contents have demonstrated that graphitic $\mathrm{N}$ and Fe-containing active sites are critical to promoting the ORR. The outstanding electrochemical performance of this material together with the facile preparation technique suggests that these catalysts could potentially replace $\mathrm{Pt} / \mathrm{C}$ catalysts in practical applications. 

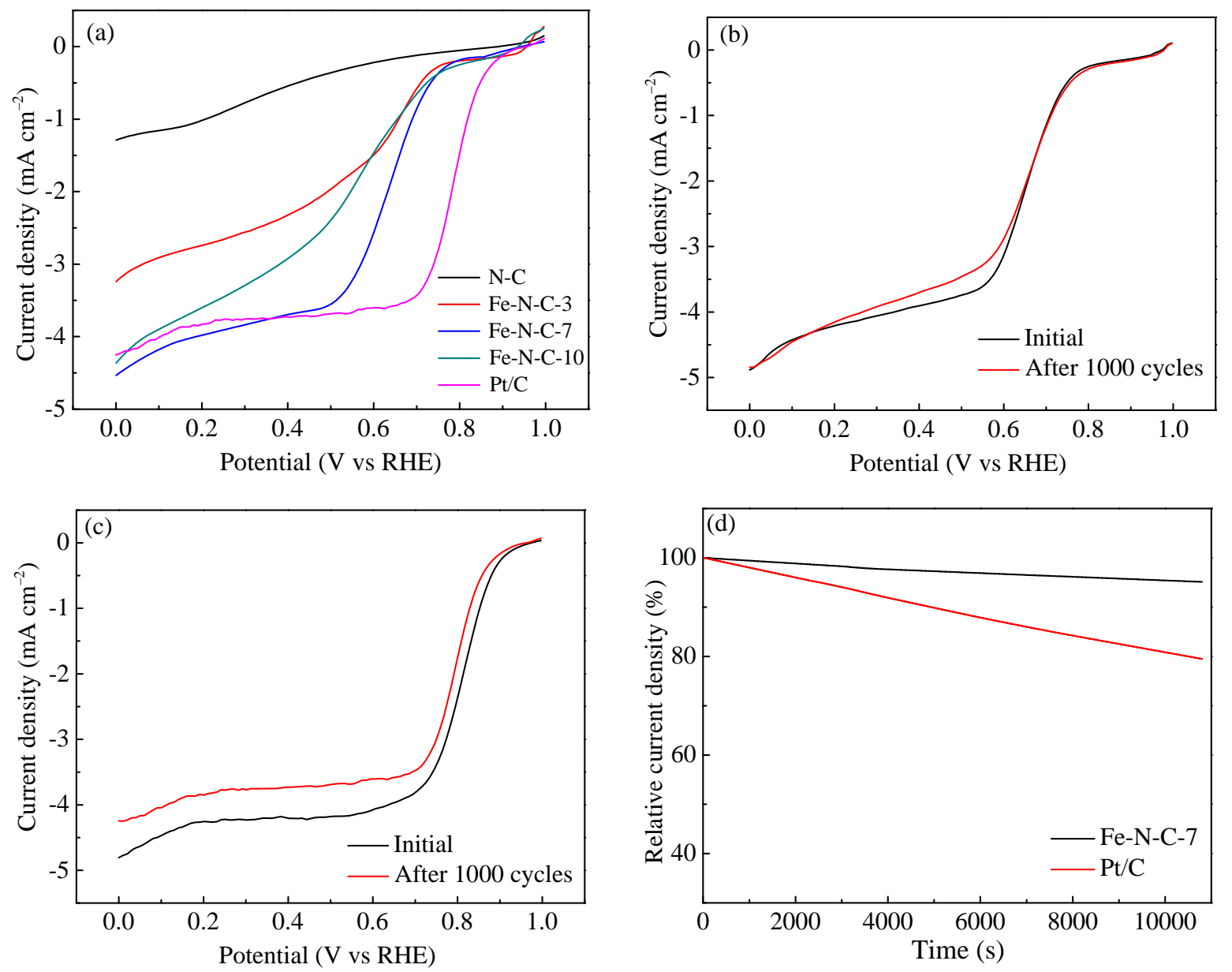

Fig. 11. (a) RDE polarization curves for catalysts with different Fe contents and a commercial Pt/C catalyst; LSV curves of Fe-N-C-7 (b) and commercial Pt/C (c) catalysts before and after $1000 \mathrm{CV}$ cycles; (d) chronoamperometric responses of the Fe-N-C-7 and Pt/C at $0.5 \mathrm{~V}$ ( $v s$ RHE) in $\mathrm{O}_{2}-\mathrm{saturated}$ $0.5 \mathrm{~mol} \mathrm{~L}^{-1} \mathrm{H}_{2} \mathrm{SO}_{4}$ at a rotation rate of $1600 \mathrm{r} \mathrm{min}^{-1}$.

\section{References}

[1] M. Lefèvre, E. Proietti, F. Jaouen, J. P. Dodelet, Science, 2009, 324, 71-74.

[2] K. P. Gong, F. Du, Z. H. Xia, M. Durstock, L. M. Dai, Science, 2009, 323, 760-764.

[3] W. Shi, Y. C. Wang, C. Chen, X. D. Yang, Z. Y. Zhou, S. G. Sun, Chin. J. Catal., 2016, 37, 754-759.

[4] M. Klingele, C. Van Pham, A. Fischer, S. Thiele, Fuel Cells, 2016, 16, 522-529.

[5] S. Zhang, Y. Y. Shao, G. P. Yin, Y. H. Lin, J. Mater. Chem., 2009, 19, 7995-8001.

[6] K. L. Wang, H. Q. Wang, S. Ji, H. Feng, V. Linkov, R. F. Wang, RSC Adv., 2013, 3, 12039-12042.

[7] Q. Zuo, P. P. Zhao, W. Luo, G. Z. Cheng, Nanoscale, 2016, 8, 14271-14277.

[8] Y. J. Sa, D. J. Seo, J. Woo, J. T. Lim, J. Y. Cheon, S. Y. Yang, J. M. Lee, D. Kang, T. J. Shin, H. Y. Jeong, C. S. Kim, M. G. Kim, T. Y. Kim, S. H. Joo, J. Am. Chem. Soc., 2016, 138, 15046-15056.

[9] H. J. Deng, Q. Li, J. J. Liu, F. Wang, Carbon, 2017, 112, 219-229.

[10] T. Palaniselvam, V. Kashyap, S. N. Bhange, J. Beak, S. Kurungot, $A d v$. Funct. Mater., 2016, 26, 2150-2162.

[11] J. Wei, Y. Liang, Y. X. Hu, B. Kong, G. P. Simon, J. Zhang, S. P. Jiang, H.
J. Wang, Angew. Chem. Int. Ed., 2016, 55, 1355-1359.

[12] S. P. Wang, M. L. Zhu, X. B. Bao, J. Wang, C. H. Chen, H. R. Li, Y. Wang, Chem CatChem, 2015, 7, 2937-2944.

[13] Y. Nie, X. H. Xie, S. G. Chen, W. Ding, X. Q. Qi, Y. Wang, J. Wang, W. Li, Z. P. Wei, M. H. Shao, Electrochim. Acta, 2016, 187, 153-160.

[14] Z. W. Chen, D. Higgins, A. P. Yu, L. Zhang, J. J. Zhang, Energy Environ. Sci., 2011, 4, 3167-3192.

[15] N. A. Karim, S. K. Kamarudin, Appl. Energy, 2013, 103, 212-220.

[16] M. L. Dou, D. P. He, W. H. Shao, H. J. Liu, F. Wang, L. M. Dai, Chem. Eur. J., 2016, 22, 2896-2901.

[17] Y. F. Yao, Y. You, G. X. Zhang, J. G. Liu, H. R. Sun, Z. G. Zou, S. H. Sun, ACS Appl. Mater. Interfaces, 2016, 8, 6464-6471.

[18] X. J. Cui, J. P. Xiao, Y. H. Wu, P. P. Du, R. Si, H. X. Yang, H. F. Tian, J. Q. Li, W. H. Zhang, D. H. Deng, X. H. Bao, Angew. Chem. Int. Ed., 2016, 55, 6708-6712.

[19] S. Dresp, F. Luo, R. Schmack, S. Kuhl, M. Gliech, P. Strasser, Energy Environ. Sci., 2016, 9, 2020-2024.

[20] C. Santoro, A. Serov, R. Gokhale, S. Rojas-Carbonell, L. Stariha, J. Gordon, K. Artyushkova, P. Atanassov, Appl. Catal. B, 2017, 205, 24-33.

[21] C. Chen, Z. Y. Zhou, Y. C. Wang, X. Zhang, X. D. Yang, X. S. Zhang, S. G. Sun, Chin. J. Catal., 2017, 38, 673-682.

[22] R. J. Jasinski, Nature, 1964, 201, 1212-1213.

[23] H. W. Liang, W. Wei, Z. S. Wu, X. L. Feng, K. Mullen, J. Am. Chem. 


\title{
Graphical Abstract
}

Chin. J. Catal., 2017, 38: 1668-1679 doi: 10.1016/S1872-2067(17)62885-7

\section{High performance ORR electrocatalysts prepared via one-step pyrolysis of riboflavin}

Yuxiao Deng, Haixin Huangfu, Shuihua Tang *, Jie Li Southwest Petroleum University

We report the synthesis of $\mathrm{Fe}-\mathrm{N}-\mathrm{C}$ catalysts via one-step pyrolysis using riboflavin as a cost-effective, nontoxic carbon and nitrogen precursor. A catalyst containing $7 \mathrm{wt} \% \mathrm{Fe}$ demonstrates an excellent oxygen reduction reaction activity and stability.

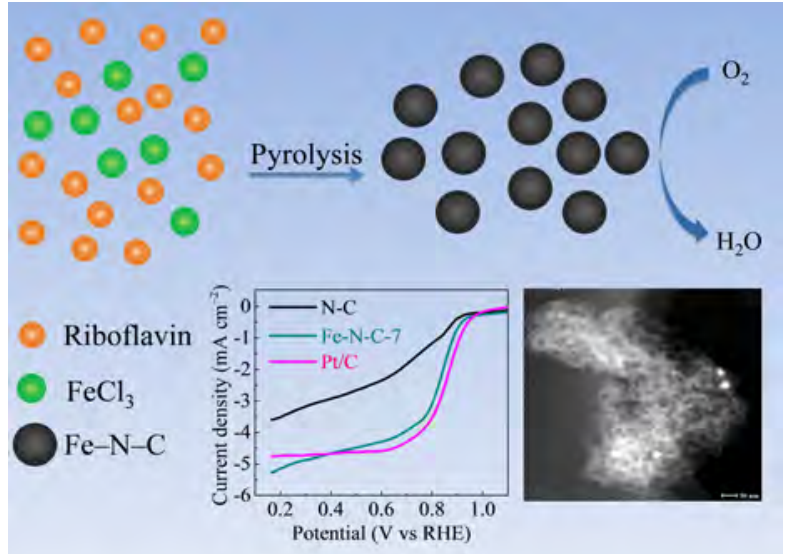

Soc., 2013, 135, 16002-16005.

[24] R. Gokhale, Y. C. Chen, A. Serov, K. Artyushkova, P. Atanassov, Electrochim. Acta, 2017, 224, 49-55.

[25] C. S. He, T. T. Zhang, F. Z. Sun, C. Q. Li, Y. Q. Lin, Electrochim. Acta, 2017, 231, 549-556.

[26] E. Proietti, F. Jaouen, M. Lefèvre, N. Larouche, J. Tian, J. Herranz, J. P. Dodelet, Nat. Commun., 2011, 1427, 1-9.

[27] G. Wu, K. L. More, C. M. Johnston, P. Zelenay, Science, 2011, 332, 443-447.

[28] L. Xu, G. S. Pan, X. L. Shi, C. L. Zou, Y. Zhou, G. H. Luo, G. P. Chen, Electrochim. Acta, 2015, 177, 57-64.

[29] S. J. Chao, Z. Y. Bai, Q. Cui, H. Y. Yan, K. Wang, L. Yang, Carbon, 2015, 82, 77-86.

[30] S. M. Unni, S. Ramadas, R. Lllathvalappil, S. N. Bhange, S. Kurungot, J. Mater. Chem. A, 2015, 3, 4361-4367.

[31] W. Yan, L. Wang, C. Chen, D. Zhang, A. J. Li, Z. Yao, L. Y. Shi, Electrochim. Acta, 2016, 188, 230-239.

[32] X. X. Liu, Y. H. Wang, L. Dong, X. Chen, G. X. Xin, Y. Zhang, J. B. Zang, Electrochim. Acta, 2016, 194, 161-167.

[33] W. J. Jiang, L. Gu, L. Li, Y. Zhang, X. Zhang, L. J. Zhang, J. Q. Wang, J. S. Hu, Z. Wei, L. J. Wan, J. Am. Chem. Soc., 2016, 138, 3570-3578.

[34] S. Lee, D. H. Kwak, S. B. Han, E. T. Hwang, M. C. Kim, J. Y. Lee, Y. W. Lee, K. W. Park, Electrochim. Acta, 2016, 191, 805-812.

[35] L. L. Feng, G. T. Yu, Y. Y. Wu, G. D. Li, H. Li, Y. H. Sun, T. Asefa, W.
Chen, X. X. Zou, J. Am. Chem. Soc., 2015, 137, 14023-14026.

[36] N. Ahmad, M. Alam, M. A. N. Al-Otaibi, Prog. React. Kinet. Mechan., 2015, 40, 86-94.

[37] J. Masłowska, M. Malicka, J. Therm. Anal., 1988, 34, 3-9.

[38] S. Karthikeyan, Arch. Phys. Res., 2011, 2, 72-79.

[39] S. J. Ye, F. Wei, Analyst, 2011, 136, 2489-2494.

[40] Z. L. Wang, X. B. Zhang, X. J. Liu, M. F. Lv, K. Y. Yang, J. Meng, Carbon, 2011, 49, 161-169.

[41] R. V. Jagadeesh, A. E. Surkus, H. Junge, M. M. Pohl, J. Radnik, J. Rabeah, H. Huan, V. Schünemann, A. Brückner, M. Beller, Science, 2013, 342, 1073-1076.

[42] L. Z. Gu, L. H. Jiang, X. N. Li, J. T. Jin, G. Q. Sun, Chin. J. Catal., 2016, 37, 539-548.

[43] Y. Zhang, L. B. Huang, W. J. Jiang, X. Zhang, Y. Y. Chen, Z. D. Wei, L. J. Wan, J. S. Hu, J. Mater. Chem. A, 2016, 4, 7781-7787.

[44] L. F. Lai, J. R. Potts, D. Zhan, L. Wang, C. K. Poh, C. H. Tang, H. Gong, Z. X. Shen, J. Y. Lin, R. S. Ruoff, Energy Environ. Sci., 2012, 5, 7936-7942.

[45] R. L. Liu, D. Q. Wu, X. L. Feng, K. Müllen, Angew. Chem. Int. Ed., 2010, 49, 2565-2569.

[46] Z. H. Wen, S. Q. Ci, F. Zhang, X. L. Feng, S. M. Cui, S. Mao, S. L. Luo, Z. He, J. H. Chen, Adv. Mater., 2012, 24, 1399-1404.

[47] L. Wang, J. Yin, L. Zhao, C. G. Tian, P. Yu, J. Q. Wang, H. G. Fu, Chem. Commun., 2013, 49, 3022-3024.

\section{一步热解核黄素制备高性能氧还原反应电催化剂}

\author{
邓玉波, 皇甫海新, 唐水花, 李 杰 \\ 西南石油大学材料科学与工程学院油气藏地质与开发国家重点实验室, 四川成都610500
}

摘要: 质子交换膜燃料电池具有零污染、能量密度高、操作温度低和超静低音等优点, 因而广泛应用于新能源汽车动力电 源. 然而质子交换膜燃料电池阴极氧还原反应(ORR)过程缓慢且复杂, 因此需要大量的高性能ORR电催化剂. 商品铂基催 化剂是目前最为广泛使用的ORR催化剂, 然而其高昂的价格阻碍了燃料电池汽车的商业化进程. 因此, 近年来人们致力于 研发高性能的非贵金属ORR催化剂, 并成功获得了具有高ORR活性及优异稳定性的催化剂. 然而开发贵金属替代催化剂 还存在制备过程较为复杂、单体有毒等缺点.

核黄素具有成本低廉、无毒、氮含量高等优点, 本文将其直接作为碳源和氮源, 以无水氯化铁为铁前驱体, 通过简单的 一步热解法制备了高性能的Fe-N-C催化剂. 表征结果表明, 合成的催化剂表面由于氮的掺杂导致石墨烯存在较多的缺陷, 其比表面积为 $301 \mathrm{~m}^{2} \mathrm{~g}^{-1}$ 且孔径分布主要位于 $45 \mathrm{~nm}$ 处; 催化剂由很薄、卷曲的石墨烯片层和一些颗粒组成, 其中的碳材料 
高度石墨化且存在 $\mathrm{Fe}_{2} \mathrm{O}_{3}$ 晶体. 结合X射线光电子能谱和催化剂的ORR活性, 推导出石墨化氮为ORR的主要活性位, 铁在 ORR反应中也起着重要作用. 在氧气饱和的 $0.1 \mathrm{~mol} \mathrm{~L}^{-1} \mathrm{KOH}$ 溶液中, $\mathrm{Fe}-\mathrm{N}-\mathrm{C}$ 催化剂的ORR活性达到 $4.16 \mathrm{~mA} \mathrm{~cm}{ }^{-2}$, 与商品 $\mathrm{Pt} / \mathrm{C}$ 催化剂相当 $\left(4.46 \mathrm{~mA} \mathrm{~cm}{ }^{-2}\right.$ ). 采用计时电流法在 $0.66 \mathrm{~V}$ (相对于RHE电位)下运行 $3 \mathrm{~h}$ 后, Fe- $\mathrm{N}-\mathrm{C}$ 催化剂电流仅下降了 $3 \%$, 而 Pt/C 催化剂下降了 $40 \%$, 表明 $\mathrm{Fe}-\mathrm{N}-\mathrm{C}$ 催化剂与 $\mathrm{Pt} / \mathrm{C}$ 催化剂具有相近的ORR活性, 但稳定性比 Pt/C催化剂更出色. 测试结 果表明, Fe-N-C催化剂的抗甲醇毒化性能远优于 $\mathrm{Pt} /$ C催化剂. 在酸性介质中, Fe-N-C催化剂的ORR活性比Pt/C催化剂低, 但稳定性更高. 总之, 该 $\mathrm{Fe}-\mathrm{N}-\mathrm{C}$ 催化剂在碱性介质中有较高的活性和稳定性, 在酸性介质中有较高的稳定性. 因此, 我们 采用廉价、无毒的核黄素作为碳氮源, 通过简单的一步热解法制备出的Fe-N-C催化剂能较好地满足燃料电池ORR催化剂 高性能和低成本的要求, 具有很好的应用前景.

关键词: 核黄素; 热解; 氧气还原反应; 氯化铁; 电催化剂

收稿日期: 2017-05-04. 接受日期: 2017-07-03. 出版日期: 2017-10-05.

*通讯联系人. 电话/传真: (028)83032879; 电子信箱: spraytang@hotmail.com

基金来源：催化基础国家重点实验室开放项目 $(\mathrm{N}-14-1)$; 教育部海外留学归国人员科研启动项目; 成都科技局国际合作项目.

本文的英文电子版由Elsevier出版社在ScienceDirect上出版(http://www.sciencedirect.com/science/journal/18722067). 